Open Innovation: Old Ideas in a fancy tuxedo remedy a false dichotomy.

\author{
Paul Trott \& Dap Hartmann
}

Delft University of Technology

Faculty of Technology, Policy \& Management

Section of Technology Strategy \& Entrepreneurship

Jaffalaan 5

2628 BX Delft

P.O. Box 5015

2600 GA Delft

The Netherlands

All future correspondence to:

$$
\text { Paul Trott }
$$

Email: paul.trott@port.ac.uk

Tel: +44(0)2392 844245 


\title{
Open Innovation: Old Ideas in a fancy tuxedo remedy a false dichotomy.
}

\begin{abstract}
The concept of 'open innovation' has received a considerable amount of coverage within the academic literature and beyond. Much of this seems to have been without much critical analysis of the evidence. In this chapter we show how Chesbrough creates a false dichotomy by arguing that open innovation is the only alternative to a closed innovation model. We systematically examine the six principles of the open innovation concept and show how the Open Innovation paradigm has created a partial perception by describing something which is undoubtedly true in itself (the limitations of closed innovation principles), but false in conveying the wrong impression that firms today follow these principles. We hope that our examination and scrutiny of the 'open innovation' concept contributes to the debate on innovation management and helps enrich our understanding.
\end{abstract}

Key words: Open Innovation; Technology Transfer; Innovation. 


\section{Introduction}

In the four years since the publication of our original paper (Trott \& Hartmann, 2009), we have received numerous email correspondence from scholars of innovation management thanking us for our critique. In this chapter we have added a discussion at the end about the increasing number of alleged industrial espionage cases in the business press. It may be that together with an open innovation strategy a firm needs also to adopt a tight IP protection strategy. We also discuss and acknowledge a few of the significant papers that have made useful contributions to this stream of research.

While Chesbrough $(2003 ; 2006)$ partly acknowledges the rich source of antecedents to the 'open innovation paradigm' there may be many scholars of R\&D management and innovation management who would argue that this paradigm represents little more than the repackaging and representation of concepts and findings presented over the past forty years within the literature on innovation management. In short, it is old wine in new bottles. Since we published our original paper (Trott \& Hartmann, 2009) open innovation has continued to remain a popular subject of interest to both practitioners and academics alike. The intention of our paper was to try to raise a few issues of critique to a concept that we felt had emerged onto the innovation studies field with very little academic criticism. Since then there have been hundreds of papers on open innovation but only a few that have provided a critique (Dahlander \& Gann 2010; Enkel \& Lenz, 2009; Huizingh, 2011).

Within the field of R\&D Management it is the pioneering work of Alan Pearson and Derek Ball more than thirty years ago that has done so much to develop thinking in this area (cf. Pearson et al., 1979; Griffiths \& Pearson, 1973). With regards to innovation management, the network model of innovation, advocated by Rothwell \& Zegveld (1985) more than twenty years ago, emphasised the need for external linkages within the innovation process. Moreover, as far back as 1959, Carter \& Williams uncovered that a key characteristic of technically progressive firms was their high quality of incoming information. Indeed, Thomas Allen's work on Gatekeepers in the 1960s also showed the importance of good external linkages to acquire information and knowledge from outside the organisation (Allen, 1969). SPRU's Project SAPPHO (1974) also confirmed the need for high quality external linkages in successful innovation. Clearly, there is plenty of evidence from many years ago stressing the need for firms to work beyond their own boundaries. In addition, previous research has shown that industrial companies that conduct their own $R \& D$ are better able to access externally available information (e.g. Tilton, 1971; Allen, 1977, Mowery, 1983; Cohen \& Levinthal, 1989). So, R\&D departments have long recognised the importance of information and knowledge beyond their own organisations. Moreover, substantial efforts have been undertaken to improve the 
ability of firms to acquire external knowledge. For example, firms have spent large sums of money addressing issues such as the not invented here syndrome (NIH), scanning and networking, and absorptive capacity. Furthermore, sixteen years ago, Rothwell (1992) presented the case for a $5^{\text {th }}$ generation model of R\&D management, where he emphasised the need for increased external focus utilising information technologies. Obviously, the need for firms to adopt a more outward-looking focus to their R\&D, technology management and NPD has been repeatedly stressed by many authors. Significantly, Tidd (1993) explained how an open and connected model of innovation facilitates the development of products and services that cross traditional technological and market boundaries in the home automotion industry. Furthermore, there has been research that examines specific issues with respect to increasing collaborations amongst firms. For example, Hoecht \& Trott (1999) discussed the problems of information leakage with respect to open and closed sytems of technology acquisition. It is hardly surprising then that some within the field raised their eyebrows at the suggestion that innovation needs to adopt a new paradigm, one that is 'open' rather than closed.

To help set the scene for what seems to have been a widespread uncritical adoption of the open innovation concept, Table 1 summarises the wide publicity that it has received within the innovation management literature. This table also presents a thematic analysis of papers and books that cite the term 'open innovation'.

Table 1: A summary of the widespread adoption of the 'open innovation' notion (grouped into the themes found in the existing literature)

\begin{tabular}{|c|c|}
\hline Themes & References \\
\hline $\begin{array}{l}\text { The Notion of Open } \\
\text { Innovation }\end{array}$ & $\begin{array}{l}\text { Chesbrough (2003a, 2003b, 2003c, 2004, 2006); Chiaromonte (2006); } \\
\text { Gassmann \& Reepmeyer (2005); Gaule (2006); Gruber \& Henkel (2006); } \\
\text { Motzek (2007); West \& Gallagher (2006); West, Vanhaverbeke, \& } \\
\text { Chesbrough (2006) }\end{array}$ \\
\hline Business models & $\begin{array}{l}\text { Chesbrough (2003c, 2007); Chesbrough \& Schwartz (2007); Van der Meer } \\
\text { (2007) }\end{array}$ \\
\hline $\begin{array}{l}\text { Organizational design and } \\
\text { boundaries of the firm }\end{array}$ & $\begin{array}{l}\text { Brown \& Hagel (2006); Chesbrough (2003b); Dahlander \& Wallin (2006); } \\
\text { Dittrich \& Duysters (2007); Fetterhoff \& Voelkel (2006); Jacobides \& } \\
\text { Billinger (2006); Lichtentaler \& Ernst (2006); Lichtenthaler (2007a, } \\
\text { 2007b); Simard \& West (2006), Tao \& Magnotta (2006) }\end{array}$ \\
\hline Leadership and culture & $\begin{array}{l}\text { Dodgson, Gann \& Salter (2006); Fleming \& Waguespack (2007); } \\
\text { Witzeman et al. (2006) }\end{array}$ \\
\hline Tools and technologies & $\begin{array}{l}\text { Dodgson, Gann \& Salter (2006); Enkel, Kausch \& Gassmann (2005); } \\
\text { Gassmann, Sandmeier \& Wecht (2006); Henkel (2006); Huston \& Sakkab } \\
(2006,2007) \text {; Piller \& Walcher (2006); Tao \& Magnotta (2006) }\end{array}$ \\
\hline IP, patenting and appropriation & $\begin{array}{l}\text { Chesbrough (2003a); Henkel (2006); Hurmelinna, Kyläheiko \& Jauhiainen } \\
\text { (2005) }\end{array}$ \\
\hline $\begin{array}{l}\text { Industrial dynamics and } \\
\text { manufacturing }\end{array}$ & $\begin{array}{l}\text { Bromley (2004); Christensen, Olesen \& Kjaer (2005); Cooke (2005); } \\
\text { Vanhaverbeke (2006) }\end{array}$ \\
\hline
\end{tabular}

Source: Fredberg et al. (2008). 
Chesbrough (2003) presents six notions that lie behind the so called closed model of innovation (see Table 2). The problem here is that he uses a straw man argument, which misrepresents the true position of innovation management today. Creating this fallacy about 'closed innovation' systems makes it is easy to refute and demolish it (as he does), which is what should happen if it were at all true. However, it is not, and certainly not within enlightened firms. Indeed, it is so misleading and inaccurate as to be offensive to the progressive firms who have studied $R \& D$ management and invested large sums of money in their own R\&D processes. Given this historical backdrop, the next section examines the so called principles of the so called closed model of innovation against the established innovation management literature.

Table 2: Contrasting 'closed innovation' principles and 'open innovation' principles

\begin{tabular}{|l|l|l|}
\hline & Closed innovation principles & Open innovation principles \\
\hline i & The smart people in our field work for us. & $\begin{array}{l}\text { Not all of the smart people work for us so we must } \\
\text { find and tap into the knowledge and expertise of bright } \\
\text { individuals outside our company. }\end{array}$ \\
\hline ii & $\begin{array}{l}\text { To profit from R\&D, we must discover, } \\
\text { develop, produce and ship it ourselves. }\end{array}$ & $\begin{array}{l}\text { External R\&D can create significant value; internal } \\
\text { R\&D is needed to claim some portion of that value. }\end{array}$ \\
\hline iii & $\begin{array}{l}\text { If we discover it ourselves, we will get it to } \\
\text { market first. }\end{array}$ & $\begin{array}{l}\text { We don't have to originate the research in order to } \\
\text { profit from it. }\end{array}$ \\
\hline iv & $\begin{array}{l}\text { If we are the first to commercialize an } \\
\text { innovation, we will win. }\end{array}$ & $\begin{array}{l}\text { Building a better business model is better than getting } \\
\text { to market first. }\end{array}$ \\
\hline v & $\begin{array}{l}\text { If we create the most and best ideas in the } \\
\text { industry, we will win. }\end{array}$ & $\begin{array}{l}\text { If we make the best use of internal and external ideas, } \\
\text { we will win. }\end{array}$ \\
\hline vi & $\begin{array}{l}\text { We should control our intellectual property } \\
\text { (IP) so that our competitors do not profit from } \\
\text { our ideas. }\end{array}$ & $\begin{array}{l}\text { We should profit from others' use of our IP, and we } \\
\text { should buy others' IP whenever it advances our own } \\
\text { business model. }\end{array}$ \\
\hline
\end{tabular}

Source: Chesbrough (2003).

\section{An examination of the evidence of the closed innovation principles}

\section{i. The smart people in our field work for us.}

The notion that the 'old' closed model of innovation is based on the premise that firms believed they employed all the smart people is misguided. As far back as 1919, UK chemical industry was very aware that German chemical firms were extremely well advanced in industrial $R \& D$, as the following excerpt from a contemporary document shows:

One of the most striking features in the works visited is the application in the broadest sense of science to chemical industry. This is naturally very prominent in the triumvirate of the Bayer, Farbwerke Hoechst and the BASF, but it is equally noticeable in many of the smaller undertakings. The lavish and apparently unstinted monetary outlay on laboratories, libraries 
and technical staff implies implicit confidence on the part of the leaders of the industry in the ability to repay with interest heavy initial expenditure.

(Source: ABCM (1919) Report of the British Chemical Mission on Chemical Factories in the Occupied Area of Germany.)

It was Thomas Allen of MIT who in the early 1960s identified that there was much technology and expertise beyond the boundary of the firm (Allen, 1969). His work identified and popularized the role of the gatekeeper: someone who was able to help link scientists within the firm to groups of scientists outside the firm so they may exchange knowledge and information which improves the performance of R\&D research groups. Michael Tushman added to this body of work by exploring the wider notion of boundary spanners: those individuals (not just within an R\&D setting) who collect and exchange knowledge and information on behalf of the firm (Tushman, 1977). These significant bodies of work are conveniently overlooked in order to strengthen the first principle of the closed innovation model.

The innovation literature for many years has emphasized interaction. Indeed, innovation has been described as an information-creation process that arises out of social interaction. In effect, the firm provides a structure within which the creative process is located (Nonaka \& Kenney, 1991). It is these interactions that provide the opportunity for thoughts, potential ideas and views to be shared and exchanged. This view is supported by a study of Japanese firms (Nonaka, 1991) where the creation of new knowledge within an organization depends on tapping the tacit and often highly subjective insights, intuitions and hunches of individual employees and making those insights available for testing and use by the organization as a whole. This implies that certain knowledge and skills, embodied in the term 'know-how', are not easily understood; moreover they are less able to be communicated. This would suggest that to gain access to such knowledge one may have to be practicing in this or related areas of knowledge. Cohen \& Levinthal (1990: 130) refer to this condition as 'lockout', suggesting that failure to invest in research and technology will limit the ability of an organization to capture technological opportunities: 'once off the technological escalator it is difficult to get back on'.

So, the available literature informs us that $R \& D$ managers have recognized for over 100 years that not all knowledge and expertise resides within their firm. Moreover, for the past fifty years R\&D Managers have been exploring how best to exploit knowledge beyond the firm.

\section{ii. To profit from $R \& D$, we must discover, develop and ship it ourselves.}

Technology partnerships between and in some cases among organizations have been rising rapidly since the 1970s. From 1976 to 1987, the annual number of new joint ventures rose six fold; by 
1987, three-quarters of these were in high-technology industries (Faulkner, 1995; Kaufman et al., 2000; Lewis, 1990). As the costs, including risk associated with R\&D efforts, continued to increase, no company could remain a 'technology island' and stay competitive. Vyas et al., 1995 suggested that we were witnessing the fall of the 'go-it-alone' strategy and the rise of the octopus strategy. This was recognition that businesses were slowly beginning to broaden their view of their business environment from the traditional 'go-it-alone' perspective of individual firms competing against each other. The formation of strategic alliances meant that strategic power now resides in sets of firms acting together. The development of cell phones, treatments for viruses such as AIDS, aircraft manufacture and motor cars are all dominated by global competitive battles between groups of firms. The success of the European Airbus strategic alliance is a case in point. Formed in 1969 as a joint venture between the German firm MBB and the French firm Aerospatiale, it was later joined by CASA of Spain and British Aerospace of the United Kingdom. The Airbus A300 range of civilian aircraft achieved great success in the 1990s securing large orders for aircraft ahead of its major rival Boeing.

Further evidence that co-operation and alliances between firms is nothing new can be illustrated by the wide types of alliances that exist. Moreover, they can involve a customer, a supplier or even a competitor (Chan \& Heide, 1993). The literature has identified at least eight generic types of strategic alliance (Bleeke \& Ernst, 1993; Gulati, 1995; Faulkner, 1995; Conway \& Stewart, 1998): licensing, supplier relations, outsourcing, joint venture, collaboration (non-joint ventures), $R \& D$ consortia, industry clusters, innovation networks.

In addition, the notion within the 'closed innovation' model that firms have been undertaking all the activities including discovering, manufacturing and distributing themselves is misleading as Table 3 clearly illustrates.

Table 3: Compilation of reasons for entering a strategic alliance

\begin{tabular}{|l|l|}
\hline Reasons & Examples \\
\hline $\begin{array}{l}\text { Improved access to capital and } \\
\text { new business }\end{array}$ & $\begin{array}{l}\text { European Airbus to enable companies to compete with Boeing and } \\
\text { MacDonnell Douglas }\end{array}$ \\
\hline Greater technical critical mass & $\begin{array}{l}\text { Alliance between Phillips and LG, Korea. Provides access to Phillips' } \\
\text { technology and lower manufacturing costs in Korea. }\end{array}$ \\
\hline Shared risk and liability & $\begin{array}{l}\text { Sony-Ericsson, a joint venture between two electronics firms to try to } \\
\text { dominate cell phone handset market }\end{array}$ \\
\hline $\begin{array}{l}\text { Better relationships with strategic } \\
\text { partners }\end{array}$ & European Airbus \\
\hline Technology transfer benefits & Customer supplier alliances, e.g. VW and Bosch \\
\hline
\end{tabular}




\begin{tabular}{|l|l|}
\hline Reduce R\&D costs & GEC and Siemens 60/40 share of telecommunications joint venture: GPT \\
\hline Use of distribution skills & Pixar and Disney \\
\hline Access to marketing strengths & NMB, Japan and Intel; NMB has access to Intel's marketing \\
\hline Access to technology & $\begin{array}{l}\text { Ericsson gained access to Sony's multi-media technology for third- } \\
\text { generation cell phones }\end{array}$ \\
\hline Standardisation & Attempt by Sony to get Betamax technology as industry standard \\
\hline By-product utilisation & GlaxoSmithKline and Matsushita, Canon, Fuji \\
\hline Management skills & J Sainsbury and Bank of Scotland; Sainsbury accessed financial skills \\
\hline
\end{tabular}

Sources: Littler (1993), Chan \& Heide (1993), Harney (2001), Budden (2003).

Finally, the open innovation concept seems to overlook all the research on technology transfer and absorptive capacity, which emphasized the need to focus efforts not just on accessing technology, but also on recognizing that in order to profit from technology developed outside the organization a firm must undertake R\&D to absorb the benefits (Cohen \& Levinthal, 1989; Trott \& Cordey-Hayes, 1993).

One of the more challenging issues for R\&D Managers is when to outsource R\&D activities; with the inherent risks associated with this activity of giving away critical core competences to others.

iii. If we discover it ourselves, we will get it to market first.

The industrial $R \& D$ landscape is full of evidence to the contrary of this third principle of the closed innovation model. For example, Corning is unique among major corporations in deriving the majority of its turnover from joint ventures and alliances. The company has a long and impressive heritage: as a specialist glass manufacturer it had its own R\&D laboratory as far back as 1908. In the 1930s it began combining its $R \& D$ with other firms in other industries, giving it access to a wide variety of growth markets. An alliance with PPG gave it access to the flat glass building market; an alliance with Owens provided access to the glass fibres market and an alliance with Dow Chemicals provided it with an opportunity to enter the silicon products market. Corning now has a network of strategic alliances based on a range of different technologies. These technology alliances deliver revenue in excess of its own turnover. Similarly, Xerox' Palo Alto laboratories in Silicon Valley were responsible for a number of breakthrough technologies including the graphical-user-interface technology that later became incorporated into the mouse we use today. Yet, clearly Xerox was unable to profit from this technology. 
R\&D activities have changed dramatically since 1950 . The past 20 years have witnessed enormous changes in the way companies manage their technological resources and in particular their research and development. There are numerous factors that have contributed to these changes. Rothwell \& Zegveld (1985) identify three important factors:

- Technology explosion. An estimated 90 per cent of our present technical knowledge has been generated during the last 55 years.

- Shortening of the technology cycle. The technology cycle includes scientific and technological developments prior to the traditional product life cycle. These cycles have been slowly shortening, forcing companies to focus their efforts on product development. For example, the market life of high volume production cars has decreased from approximately 10 years in the 1960s to approximately six years in the 1990s. In some cases a particular model may be restyled after only three years.

- Globalisation of technology. Countries on the Pacific Rim have demonstrated an ability to acquire and assimilate technology into new products. This has resulted in a substantial increase in technology transfer in the form of licensing and strategic alliances.

The effect of these macro-factors was a shift in emphasis within industrial $R \& D$ from an internal to an external focus. In a study of firms in Sweden, Japan and the United States Granstrand et al. (1992) revealed that the external acquisition of technology was the most prominent technology management issue in multi-technology corporations. Traditionally, $\mathrm{R} \& \mathrm{D}$ management, particularly in Western technology-based companies, has been management of internal R\&D. It could be argued that one of the most noticeable features of Japanese companies since the Second World War has been their ability to successfully acquire and utilise technology from other companies around the world. Granstrand et al. (1992) suggest that the external acquisition of technology exposes technology managers to new responsibilities. Although this implies that acquiring technology from outside the organization is something new, this is clearly not the case, as the long history of licensing agreements shows. However, the importance now placed on technology acquisition by technology-based companies reveals a departure from a focus on internal $R \& D$ and an acknowledgement that internal $R \& D$ is now only one of many technology development options available. The technology base of a company is viewed as an asset; it represents the technological capability of that company. The different acquisition strategies available involve varying degrees of organizational and managerial integration. For example, internal R\&D is viewed as the most integrated technology-acquisition strategy with technology scanning the least integrated strategy. Technology scanning is rather narrowly defined by Granstrand et al. (1992) as both illegal and legal forms of acquiring technological know-how from outside. 
The classification of technology-acquisition strategies offered by Granstrand et al. (1995) provides an illustration of the numerous ways of acquiring external technology. Other classifications can be found in the technology transfer literature: Auster (1987); Chesnais (1988); Hagedoorn (1990); Lefever (1992).

It is necessary to counsel caution here, for there are clear potential financial benefits from being the owner of the proprietary technology and having secure intellectual property protection. For example, Pilkington developed the float glass manufacturing process and then licensed it to every glass manufacturer in the world.

\section{iv. If we are the first to commercialize an innovation, we will win.}

Table 4 illustrate the wide range of industries that bear witness to the evidence that being first to market does not ensure victory. The innovation policy pursued by a firm cuts a wide path across functions such as manufacturing, finance, marketing, $R \& D$ and personnel, hence the importance attached to its consideration. The four broad innovation strategies commonly found in technologyintensive firms (Freeman, 1982; Maidique \& Patch, 1988) are discussed below. These are not mutually exclusive or collectively exhaustive. A wide spectrum of other strategies is logically possible; indeed, very often a firm adopts a balanced portfolio approach with a range of products. Nonetheless the key point here is that firms recognize innovation success involves more than simply being first to commercialise a technology.

\section{Leader/offensive}

The strategy here centres on the advantages to be gained from a monopoly, in this case a monopoly of the technology. The aim is to try to ensure that the product is launched into the market before the competition. This should enable the company either to adopt a price-skimming policy, or to adopt a penetration policy based on gaining a high market share. Such a strategy demands a significant $R \& D$ activity and is usually accompanied by substantial marketing resources to enable the company to promote the new product.

\section{Fast follower/defensive}

This strategy also requires a substantial technology base in order that the company may develop improved versions of the original, improved in terms of lower cost, different design, additional features, etc. The company needs to be agile in manufacturing, design and development and marketing. This will enable it to respond quickly to those companies that are first into the market. 
Without any in-house R\&D their response would have been much slower, as this would have involved substantially more learning and understanding of the technology.

\section{Cost minimisation/imitative}

This strategy is based on being a low-cost producer and success is dependent on achieving economies of scale in manufacture. The company requires exceptional skills and capabilities in production and process engineering. This is clearly similar to the defensive strategy, in that it involves following another company, except that the technology base is not usually as well developed as for the above two strategies. Technology is often licensed from other companies. This is a strategy that has been employed very effectively by the rapidly developing Asian economies. With lower labour costs these economies have offered companies the opportunity to imitate existing products at lower prices, helping them enter and gain a foothold in a market, for example footwear or electronics. From this position it is then possible to incorporate design improvements to existing products (Hobday et al 2004).

\section{Market segmentation specialist/traditional}

This strategy is based on meeting the precise requirements of a particular market segment or niche. Large-scale manufacture is not usually required and the products tend to be characterised by few product changes. They are often referred to as traditional products. Indeed, some companies promote their products by stressing the absence of any change, for example Scottish whisky manufacturers.

Significantly, there are additional advantages to being first to market, such as building a scientific and innovation reputation. Sony, for example, while it has not always maximised revenue from its innovations (Betamax technology), it has nonetheless developed an enviable position for its technology.

Table 4: Throughout the twentieth century 'Late Entrants' have been surpassing pioneers

\begin{tabular}{|c|c|c|c|}
\hline Product & Pioneer(s) & $\begin{array}{l}\text { Imitator/Later } \\
\text { Entrant(s) }\end{array}$ & Comments \\
\hline 35mm Cameras & $\begin{array}{l}\text { Leica }(1925) \\
\text { Contrax (1932) } \\
\text { Exacta }(1936)\end{array}$ & $\begin{array}{l}\text { Canon (1934) } \\
\text { Nikon (1946) } \\
\text { Nikon SLR (1959) }\end{array}$ & $\begin{array}{l}\text { The pioneer was the technology and } \\
\text { market leader for decades until the } \\
\text { Japanese copied German } \\
\text { technology, improved upon it, and } \\
\text { lowered prices. The pioneer then } \\
\text { failed to react and ended up as an } \\
\text { incidental player }\end{array}$ \\
\hline $\begin{array}{l}\text { CAT Scanners } \\
\text { (Computer Axial } \\
\text { Tomography) } \\
\end{array}$ & EMI (1972) & $\begin{array}{l}\text { Pfizer (1974) } \\
\text { Technicare (1975) } \\
\text { GE (1976) }\end{array}$ & $\begin{array}{l}\text { The pioneer had no experience in } \\
\text { the medical equipment industry. } \\
\text { Copycats ignored the patents and }\end{array}$ \\
\hline
\end{tabular}




\begin{tabular}{|c|c|c|c|}
\hline & & Johnson \& Johnson (1978) & $\begin{array}{l}\text { drove the pioneers out of business } \\
\text { with marketing distribution, and } \\
\text { financial advantages, as well as } \\
\text { extensive industry experience }\end{array}$ \\
\hline Ballpoint pens & $\begin{array}{l}\text { Reynolds (1945) } \\
\text { Eversharp (1946) }\end{array}$ & $\begin{array}{l}\text { Parker ‘Jotter' (1954) } \\
\text { Bic (1960) }\end{array}$ & $\begin{array}{l}\text { The pioneers disappeared when the } \\
\text { fad first ended in the late } 1940 \text { s. } \\
\text { Parker entered } 8 \text { years later. Bic } \\
\text { entered last and sold pens as cheap } \\
\text { disposables. }\end{array}$ \\
\hline $\begin{array}{l}\text { MRI (Magnetic } \\
\text { Resonance Imaging) }\end{array}$ & Fonar (1978) & $\begin{array}{l}\text { Johnson \& Johnson's } \\
\text { Technicare (1981) } \\
\text { General Electric (1982) }\end{array}$ & $\begin{array}{l}\text { The tiny pioneer faced the huge } \\
\text { medical equipment suppliers, which } \\
\text { easily expanded into MRIs. The } \\
\text { pioneer could not hope to match } \\
\text { their tremendous market power }\end{array}$ \\
\hline Personal Computers & $\begin{array}{l}\text { MITS Altair } 8800 \\
\text { (1975) } \\
\text { Apple II (1977) } \\
\text { Radio Shack (1977) }\end{array}$ & $\begin{array}{l}\text { IBM-PC (1981) } \\
\text { Compaq (1982) } \\
\text { Dell (1984) } \\
\text { Gateway (1985) }\end{array}$ & $\begin{array}{l}\text { The pioneers created computers for } \\
\text { hobbyists, but when the market } \\
\text { turned to business uses, IBM entered } \\
\text { and quickly dominated, using its } \\
\text { reputation and its marketing and } \\
\text { distribution skills. The cloners then } \\
\text { copied IBM's standard and sold at } \\
\text { lower prices }\end{array}$ \\
\hline VCRs & $\begin{array}{l}\text { Ampex (1956) } \\
\text { CBS-EVR (1970) } \\
\text { Sony U-matic (1971) } \\
\text { Catrivision (1972) } \\
\text { Sony Betamax (1975) }\end{array}$ & $\begin{array}{l}\text { JVC-VHS (1976) } \\
\text { RCA Selectra Vision (1977) } \\
\text { made by Matsushita }\end{array}$ & $\begin{array}{l}\text { The pioneer focused on selling to } \\
\text { broadcasters while Sony pursued the } \\
\text { home market for more than a } \\
\text { decade. Financial problems killed } \\
\text { the pioneer. Sony Betamax was the } \\
\text { first successful home VCR but was } \\
\text { quickly supplanted by VHS, a late } \\
\text { follower, which recorded for twice } \\
\text { as long. }\end{array}$ \\
\hline $\begin{array}{l}\text { Word-processing } \\
\text { software }\end{array}$ & Wordstar (1979) & $\begin{array}{l}\text { WordPerfect (1982) } \\
\text { Microsoft Word (1983) }\end{array}$ & $\begin{array}{l}\text { The pioneer was stuck with an } \\
\text { obsolete standard when it failed to } \\
\text { update. When it did update, } \\
\text { Wordstar abandoned loyal users, } \\
\text { offered no technical support, and } \\
\text { fought internally. The follower took } \\
\text { advantage. }\end{array}$ \\
\hline Web browser & $\begin{array}{l}\text { Mosaic (1993) } \\
\text { Netscape (1994) }\end{array}$ & Internet Explorer; Firefox & $\begin{array}{l}\text { Leader of the Mosaic team left to } \\
\text { form a new company netscape. In } \\
1996 \text { Netscape's market share was } \\
86 \% \text { but then Microsoft started } \\
\text { incorporating Internet Explorer with } \\
\text { its operating system. It now has } 75 \% \\
\text { market share. }\end{array}$ \\
\hline Search Engine & $\begin{array}{l}\text { Altvista (1994) } \\
\text { Yahoo (1995) }\end{array}$ & Google (2000) & $\begin{array}{l}\text { The pioneer was overhauled by the } \\
\text { late entrant that developed superior } \\
\text { algorithm facilitating more accurate } \\
\text { search. }\end{array}$ \\
\hline
\end{tabular}

Source: Trott (2008).

v. If we create the most and best ideas in the industry, we will win.

Once again a tired old argument has been put up so that it can be demolished. This principle seems to be based on the old idea that more R\&D is better, whereas firms such as $3 \mathrm{M}$ and Pilkington know all too well that increased $R \& D$ expenditure without the corresponding link to new products leads to serious questions from your shareholders. In particular, investors rightly want to know what is happening to all the money that is being poured into research and technology. Hence, it is the ability to capture ideas from $R \& D$ and convert these into products and services that people want to buy that is more significant than idea generation. 
President Kennedy's special address to the US Congress in 1961, in which he spoke of 'putting a man on the moon before the decade was out', captured the popular opinion of that time. Many believed anything was possible with sufficient investment in technology development. This notion helps to explain one of the major areas of difficulty with R\&D. Traditionally, it was viewed as a linear process, moving from research to engineering and then manufacture. That $R \& D$ was viewed as an overhead item was reinforced by Kennedy's pledge to spend 'whatever it costs', and indeed enormous financial resources were directed towards the project. Clearly, the Apollo project was a political decision - a unique situation without the usual economic or market forces at play. Nevertheless, some sectors of industry have adopted a similar approach to that used by the space programme. Vast amounts of money were poured into R\&D programmes in the belief that the interesting technology generated could then be incorporated into products (e.g., The Strategic Defense Initiative (SDI; 'Star Wars’); The International Space Station; Nuclear Fusion research). In many instances this is exactly what happened, but there were also many examples of exciting technology developed purely because it was interesting, without any consideration of the competitive market in which the business operated. Hence, many business leaders began to question the value of $R \& D$.

This, of course, was almost fifty years ago and much has changed since. We now know that the management of research and development needs to be fully integrated with the strategic management process of the business. This will enhance and support the products that marketing and sales offer and provide the company with a technical body of knowledge that can be used for future development. Too many businesses fail to integrate the management of research and technology fully into the overall business strategy process (Adler et al., 1992). A report by the European Industrial Management Association (EIRMA, 1985) recognised R\&D as having three distinct areas, each requiring investment: $R \& D$ for existing businesses, $R \& D$ for new businesses, and $R \& D$ for exploratory research. It is these basic principles that drive $\mathrm{R} \& \mathrm{D}$ today not the narrow technology focused notion that firms conduct R\&D for the sake of more technology.

\section{vi. We should control our intellectual property (IP) so that our competitors do not profit from our} ideas.

The sixth and final principle of the closed innovation model is simply unreasonable. One only has to look at the long history of licensing where firms have been trading intellectual property for decades. The exchange of patents between fierce detergent rivals $P \& G$ and Unilever in the 1970s and the buying and selling of licences between firms in the chemical industry is an accepted way of doing business in these industries. 
Famous licensing cases from Pilkington's Float Glass process to JVC's VHS cassette technology illustrate that when it comes to intellectual property firms know only too well that getting others involved is a necessary part of the process to achieve success. JVC won the VCR battle with Sony partly because it unlike Sony successfully secured joint venture partnerships and licensed its VHS technology to many other manufacturers ensuring that the VCR format was built into more machines than Sony's Betamax format. Pilkington famously developed the float glass process for the manufacture of flat glass. Pilkington quickly recognised that enormous opportunities existed through licensing the manufacturing process to other glass manufacturers, that is competitors, rather than keeping the technology to itself.

Mutual self-interest is the common dominator behind most licensing contracts, as it is in other business contracts. Licences to competitors constitute a high percentage of all licences extended; Microsoft's disk-operating system (MS-DOS) is a case in point. These normally arise out of a desire on the part of the competitor to be free of any patent infringement in its development product features or technology. They are also due to the owner of the patent seeking financial gain from the technology. Other reasons for licensing include: to avoid or settle patent infringement issues; to diversify and grow through the addition of new products; to access technology and improve the quality of existing products and or to obtain improved production or processing technology.

It is worthy of note here that following the open innovation prescription of buying and selling IP to advance our business model seems reasonable in theory. But, in practice when you are competing with other firms, trying to gain access to a technology that is already licensed to a competitor is extremely difficult. Indeed, firms frequently specify exclusive licensing arrangements to ensure others are unable to access the technology.

\section{Using a false dichotomy to introduce the concept of Open Innovation}

The Open Innovation paradigm is presented by contrasting it with the apparent old paradigm of closed innovation. Open vs. closed creates an intuitive dichotomy between the old way of doing $R \& D$ and the new way which adopts the principles of Open Innovation. It is obvious that this dichotomy is exaggerated at best and plain false in general. The convincing example of Xerox, which Chesbrough describes at length in the first chapter of his 2003 book, sets the stage for condemning the six erroneous notions of closed innovation which almost lead to the demise of this industrial giant. Xerox with its Palo Alto Reseach Center (PARC) is widely recognized as a one-of- 
a kind historical conundrum. Most business historians use Xerox as the prime example of a company with excellent $R \& D$ facilities, yet unable to convert new ideas into commercial products.

In this chapter, we show that the dichotomy between closed innovation and open innovation may be true in theory, but does not really exist in industry, certainly not to the extent of the case of Xerox. However, we recognize the advantage of using such a false dichotomy to get an important message across, even when many of the underlying principles of that message were already implemented many years ago by the majority of the companies addressed. It is a helpful and stimulating tactic to introduce a 'new concept' (such as Open Innovation) to companies that are already most of the way there. Companies which 'discover' that they have already implemented most of the principles of the new paradigm will be more eager to also consider the remaining changes needed to turn them into a genuine Open Innovator than companies that find themselves entirely stuck in the old paradigm. It is the psychology of encouraging someone who is (seemingly) already halfway there.

Natural selection (competition in a free market economy) would already have killed off companies that remained stuck in the old paradigm of closed innovation. While it is not known how many companies could have been labeled 'closed innovators' (or simply 'closed') in the past, it is obvious that such companies do not appear to exist today, except in very specialize fields with niche markets. Some prominent big corporations such as IBM and the aforementioned Xerox have unmistakably flirted with disaster by making some of the mistakes that Chesbrough lists as the notions of closed innovation (see Section 2). However, they overcame these shortcomings without the aid of the Open Innovation paradigm, which means that these ideas did already exist. Indeed, these cases are used as the inspiration to lay the foundation for the Open Innovation paradigm.

Table 1 provides evidence of the widespread adoption of the Open Innovation concept. Managers and academics are sometimes accused of jumping on bandwagons, for fear of missing the latest popular fad. Indeed, there are many examples of such mentality that have swept through otherwise sedate, serious organisations. For example, for a while, everyone was excited over something called "quality circles" and "Theory Z" forms of Japanese-style management. Then everyone went "searching for excellence" before they found "process re-engineering." More recently "disruptive innovation" has been rolling around the globe. Whether these bandwagons are driven by evidence based research or are simply fads is usually determined with the passing of time. What we must try to avoid is sloppy thinking and the uncritical adoption of concepts. The original insight and context that gave rise to the concept can get lost as people scramble to jump on the bandwagon. This leads people to focusing on things that are often irrelevant or unrelated to the benefits the insight promised to deliver (Alexander \& Korine, 2008). 


\section{Issues unresolved by Open innovation}

Despite its success - as measured by the amount of attention it has received in the R\&D literature (see Table 1), the commercial success of Chesbrough's books, and the willingness of big companies to embrace, implement and preach its principles - Open Innovation is not perfect. The most obvious shortcoming is that the model is inherently linear, and basically a variation on the well-known stage-gate model (Cooper \& Kleinschmidt, 1986) without any feedback or feed-forward mechanisms. The only distinguishing difference is that in the Open Innovation model ideas (technologies; knowledge) can freely 'fly in' and 'fly out' of the funnel that runs from opportunity scanning to business incubation. This is visualized by a funnel that contains holes which enable the exchange of ideas along the way. However, the flow of the innovation trajectory is linearly forward. New innovation models, such as the Cyclic Innovation Model (CIM; Berkhout et al., 2007) emphasize the importance of feed forward and feedback mechanisms, as well as the notion that innovation is inherently a cyclic process where new innovations build upon previous innovations. Moreover, according to CIM innovation can start anywhere within the cycle; there is no fixed point of origin like those demarking the beginning of the outdated (but still widely used) 'technologypush' and 'market-pull' models. If anything, modern innovation models should once and for all get rid of the notion of linearity in the innovation process. Hence, it will be a significant improvement when the cyclic concepts of CIM are combined with and integrated into the Open Innovation model to overcome its implicit linearity.

With all the openness that Open Innovation describes comes the potential danger of knowledge leakage. The information sharing/knowledge loss dilemma has received substantial attention in the innovation and knowledge management literature in recent years. Firms in knowledge-intensive industries in particular need to engage in collaborative $R \& D$ to sustain their competitive advantage and need to 'open up' to knowledge sharing with their partner organisations if they wish to reap the benefits of such collaboration. Inkpen \& Dinar (1998), for example, have highlighted the importance of alliance partners as a particular important source of new external knowledge and Lincoln et al. (1998) have emphasized the need for open communication and rich knowledge sharing as a key success factor for knowledge acquisition. While there is little doubt in the literature on the merits of open communication for successful learning, there is also an increasing awareness that the information sharing required to facilitate such learning can lead to the leakage of commercially sensitive knowledge (Hoecht \& Trott, 1999; Norman, 2004). Organisations participating in $R \& D$ alliances in particular face the challenge of attempting to maintain a sufficiently 'open' knowledge exchange regime for meeting their collaborative R\& D objectives 
while sufficiently controlling knowledge flows to minimise unintended leakage of sensitive knowledge and technologies (Oxley \& Sampson, 2004). The principle ways in which this trade-off can be addressed is either by careful design of suitable relationship governance structures and relationship management instruments or by attempting to limit the scope of alliance activities in terms of the degree of knowledge sharing (Oxley \& Sampson, 2004).

Clearly a strategy of open innovation may help to develop technology and business partners, but if a firm is openly sharing its knowledge and technology it should not be surprised to find a long queue of potential partners at its door. Of greater concern is that there have also been a few papers reminding practitioners and academics alike that the so-called closed model of innovation may still be most suitable for many firms. Indeed, the business press has been full of stories covering various alleged aspects of industrial espionage. Most notable of these are the Dyson case where it alleges that a former employee was hired to gather industrial secrets about its electric motors for German and Chinese firms. A similar case was revealed by GM when it alleged that a former employee was passing trade secrets about its Hybrid Technology to Chinese firms (see Table 5).

Firms needs to be careful that a partner does not simply run off with their technology. It may be that together with an open innovation strategy a firm needs also to adopt a tight IP protection strategy. In many ways we are suggesting that if you are going to negotiate with partners about technology it is far better to negotiate from a position of strength. This can be achieved with effective IP protection. Intellectual property (IP) is a company asset and should be treated and managed as such. Owning and acquiring IP will not overcome poor business strategy and make a company successful. IP is a broad concept and includes many different intangibles such as patents (inventions), copyright (works of authorship, software, drawings, etc) know-how (e.g. expertise, skilled craftsmanship, training capability, understanding of how something works), trade secrets (a protected formula or method), trademarks (logos, distinctive names), industrial design (the unique external appearance) and semi-conductor mask works (the physical design of semiconductor circuits). There are many examples of firms with exciting technology that failed to profit from it. Classic cases such as the EMI scanner (MRI) are taught to business students. This technology was developed by EMI but they failed to develop a business model to exploit it.

Table 5: Cases of alleged knowledge theft

\begin{tabular}{|l|l|l|l|}
\hline Complainant & Accused & Nature of IP & Nature of event \\
\hline GM & $\begin{array}{l}\text { Former } \\
\text { employee }\end{array}$ & Trade secrets & $\begin{array}{l}\text { A former General Motors engineer with access to } \\
\text { the automaker's hybrid technology was convicted } \\
\text { in November 2012 with her husband of stealing } \\
\text { trade secrets for possible use in China. }\end{array}$ \\
\hline Dyson & Bosch & Trade secrets & A rogue employee in Dyson's digital motors \\
\hline
\end{tabular}




\begin{tabular}{|c|c|c|c|}
\hline & & & $\begin{array}{l}\text { facility was handing company secrets to Bosch } \\
\text { divisions in the UK and in Germany. Dyson has } \\
\text { now filed proceedings against Bosch in the High } \\
\text { Court in London. }\end{array}$ \\
\hline $\begin{array}{l}\text { Pittsburgh } \\
\text { Corning Corp }\end{array}$ & & Trade secrets & $\begin{array}{l}\text { In } 2012 \text { two Chinese citizens in Kansas City, } \\
\text { Missouri, were charged with attempting to pay } \\
\$ 100,000 \text { for stolen trade secrets from Pittsburgh } \\
\text { Corning Corp, an affiliate of Corning Inc., at its } \\
\text { Sedalia, Mo. facility. The US Justice Department } \\
\text { said the pair were trying to purchase the trade } \\
\text { secrets so a rival plant could be opened in China. }\end{array}$ \\
\hline Dupont & $\begin{array}{l}\text { Pangang } \\
\text { Group Steel } \\
\text { Vanadium } \\
\text { \& Titanium } \\
\text { Co Ltd }\end{array}$ & Trade secrets & $\begin{array}{l}\text { U.S. chemicals giant Dupont (DD.N) is in the } \\
\text { midst of a legal battle over allegations that China- } \\
\text { based Pangang Group Steel Vanadium \& Titanium } \\
\text { Co Ltd conspired to steal its trade secrets. }\end{array}$ \\
\hline $\begin{array}{l}\text { Massachusetts } \\
\text { wind-energy } \\
\text { company } \\
\text { American } \\
\text { Superconductor }\end{array}$ & Employee & IP & $\begin{array}{l}\text { In 2012, an Austrian-based employee of the } \\
\text { Massachusetts wind-energy company American } \\
\text { Superconductor stole intellectual property from the } \\
\text { firm and sold it to Chinese wind turbine } \\
\text { manufacturer Sinovel for } \$ 1.5 \text { million. }\end{array}$ \\
\hline
\end{tabular}

If we now look more closely at developments in the literature, we can see useful contributions. The notion of appropriation governs a firm's ability to capture the profits generated by an innovation (Teece, 1986). It was this notion that forms the basis of recent classifications of open innovation into inbound Innovation and outbound innovation (Lichtenthaler \& Lichtenthaler, 2009; Dahlander \& Gann, 2010). Inbound open innovation refers to internal use of external knowledge, whereas outbound open innovation refers to external exploitation of internal knowledge. This relates to the processes of knowledge exploration, retention, and exploitation that can be performed either inside or outside a firm (Lichtenthaler \& Lichtenthaler, 2009).

When it comes to inbound innovation formal intellectual property rights (IPR) reduces transaction costs, hence firms often require that knowledge suppliers have formal IPR in place before they collaborate (Dahlander \& Gann, 2010). Those firms that require strong IPR to protect their knowledge remain reluctant to engage in external innovation (Gooroochurn \& Hanley, 2007). For outbound Innovation: firms that rely on trade secrets, formal agreements such as patents, copyright and trademarks, and lead time to protect their innovation are less likely to engage in external innovation and so they prefer to retain innovation in-house.

The size of a firm and its related resources is also a mediating variable here. For example, larger firms with greater co-specialized resources will be more successful in adopting inbound innovation (Licthentaler, 2008; Sandulli \& Chesbrough, 2009). Whereas, smaller companies typically lack the 
capabilities to structure the process of searching and selecting external innovation, especially regarding decisions whether to file patents or disclose or anticipating the potential value of inbound innovation (Dahlander \& Gann, 2010). Small and medium sized enterprises (SMEs) are more affected by the uncertainty of innovation projects because the failure of a project could compromise the future of the entire firm; thus, they prefer to share this uncertainty by adopting outbound innovation (Van de Vrande et al., 2009).

Another, unexpected, problem with Open Innovation are the recent findings of Hacievliyagil (2007; also Hacievliyagil, Auger \& Hartmann 2008) that, even though a company has opened up (the flow of knowledge) towards other companies, the internal boundaries of the company have tightened, decreasing and limiting the free flow of knowledge between different departments within the company. This apparent contradiction was observed within Philips and DSM, and may be a common side effect of the current implementation of Open Innovation. To verify this hypothesis, further studies are necessary of companies which adhere to the principles of Open Innovation and have (re)structured the organization accordingly.

\section{Discussion}

In this chapter we have argued support for not only the need for research to build on previous work, but also that those of us working within the field recognize the past contributions of others. The need for critical analysis within research is self-evident amongst academics. Those of us in the field would be correctly criticized if we did not hold up new concepts, theories and assertions and scrutinize them thoroughly. This is a slightly updated version of our 2009 paper (Trott \& Hartmann, 2009) in which we first presented a critical review of Open Innovation. At that time, the new concept op Open Innovation had been widely praised and adopted but no critical analysis existed of the origin of the ideas it contained and the reality of the dichotomy it pretended to solve. We feel that the Open Innovation community has given insufficient credit to previous researchers who described, analyzed and argued in favor of most of the principles on which Open Innovation was founded, long before the term for this new model was actually coined. In fact, the Open Innovation concept would gain credibility when scientific evidence for the correctness of the basic principles of the model in the existing literature is recognized appropriately.

If Open Innovation is in essence nothing new, why then has this concept been so readily embraced by firms and the R\&D community? Much of this surely is due to its simplicity (it is appealing because it is simple and retains the linear notion of science to marketplace) and the partial deception which was created by describing something which is undoubtedly true in itself (the limitations of closed innovation principles), but false in conveying the wrong impression that firms today still 
follow these principles. The open versus closed systems of innovation are presented as two alternatives faced by firms. This lends credence to the larger argument by giving the impression that the options are mutually exclusive, even though this is not the case. It is precisely the simplicity and the certainty of this logic that has enabled the design of a dichotomy. If something is not true, surely it must be false; if something is not false, surely it must be true. Stated another way: if something is wrong, then surely the opposite must be right. This sharp polarisation allows no middle ground. Yet something may be partly true and partly false.

Unmistakably, Chesbrough has been very successful in popularising the notion of technology transfer and the need to share and exchange knowledge. Indeed, it seems that in using a business strategy perspective the Open Innovation concept may have reached new audiences (e.g., CEOs of technology-intensive companies) that for so many years the innovation and R\&D literatures failed to reach. The fact that large multinational companies such as Procter \& Gamble and Philips have incorporated the principles of Open Innovation and facilitate conferences and publications on the subject deserves admiration and praise. In essence, it has created real-life laboratories (playgrounds) in which the mechanisms of Open Innovation can be studied in great detail (see, for example, Hacievliyagil, 2007 and Hacievliyagil, Auger \& Hartmann, 2008). We hope that, in the true realm of scientific experimentation, objective assessment of the results will lead to improvements in the theory of Open Innovation. What gives us cause for concern is that the CEOs that now seem to be showing interest in innovation management may become frustrated and disillusioned when it becomes clear that 'open innovation' is not a panacea. The best way to avoid this from happening is to consider Open Innovation as a work in progress. In the true spirit of openness, additions and modifications to the Open Innovation model must be welcomed. It is therefore imperative that this work in progress is scrutinized against its own prescribing principles. To paraphrase just one principle of Open Innovation (not all the smart people in our field work for us): not all good ideas in innovation originate from Harvard Business School and the Haas School of Business.

In the four years since the publication of our original paper (Trott \& Hartmann, 2009), we were pleased to see that it is one of the most cited papers published in the International Journal of Innovation Management. Despite all this attention and about three dozen papers that acknowledge (and in many cases agree with) our critical view on Open Innovation, 'the father of open innovation' (as he is referred to in Chesbrough, 2012), Henry Chesbrough, has carried on regardless despite the ten papers he has published since 2010.

\section{References}


ABCM (1919) Report of the British Chemical Mission on Chemical Factories in the Occupied Area of Germany.)

Adler, P.S., McDonald, D.W. \& MacDonald, F. (1992) 'Strategic management of technical functions', Sloan Management Review, Winter, 19-37.

Alexander, M. \& Korine, H. (2008) When You Shouldn't Go Global, Harvard Business Review, Vol. 86, (12), 70 - 77, December.

Allen, T.J. (1977) Managing the flow of technology; Cambridge Mass. MIT Press.

Allen, T.J. \& Cohen, W.M. (1969) 'Information flow in research and development laboratories', Administrative Science Quarterly, Vol. 14, No. 1, 12-19.

Auster, E.R. (1987) 'International corporate linkages: dynamic forms in changing environments', Columbia Journal of World Business, Vol. 22, No. 2, 3-6.

Berkhout, A.J., Patrick van der Duin, Dap Hartmann \& Roland Ortt, (2007), The Cyclic Nature of Innovation: Connecting Hard Sciences with Soft Values. Advances in the Study of Entrepreneurship, Innovation and Economic Growth, Vol.17, Elsevier, Amsterdam.

Bleeke, J. \& Ernst, D. (1992) Collaborating to Compete, John Wiley, New York.

Bromley, D. A. (2004) Technology policy. Technology in Society, 26(2-3): 455-468.

Brown, J. S. \& Hagel III, J. (2006) Creation nets: Getting the most from open innovation. McKinsey Quarterly(2): 40-51.

Budden, R. (2003) 'Sony-Ericsson seeks success with new phones', www.FT.com, 3 March.

Carter, C.F. \& Williams, B.R. (1959) 'The characteristics of technically progressive firms'. Journal of Industrial Economics, March, 87-104.

Chan, P.S. \& Heide, D. (1993) 'Strategic alliances in technology: key competitive weapon', Advanced Management Journal, Vol. 58, No. 4, 9-18.

Chesbrough, H. (2003a) Open Innovation: The new imperative for creating and profiting from technology, Boston, MA: Harvard Business School Press.

Chesbrough, H. (2003b) The era of open innovation. MIT Sloan Management Review, 44(3): 3541.

Chesbrough, H. (2003c) The logic of open innovation: Managing intellectual property. California Management Review, 45(3): 33-58.

Chesbrough, H. (2004) Managing open innovation. Research-Technology Management, 47(1): 2326.

Chesbrough, H. (2006). Open innovation: A new paradigm for understanding industrial innovation. In H.W. Chesbrough, W. Vanhaverbeke \& J. West (eds.), Open Innovation: Researching a New Paradigm, pp. 1-12. Oxford: Oxford University Press.

Chesbrough, HW (2007). Why companies should have open business models. MIT Sloan Management Review, 48(2), 1-22.

Chesbrough, H. (2012), Open innovation: Where we've been and where we're going, Research Technology Management 55 (4), pp. 20-27

Chesbrough, H. \& Schwartz, K. (2007) Innovating business models with codevelopment partnerships. Research-Technology Management, 50(1): 55-59.

Chesnais, F. (1988) 'Multinational enterprises and the international diffusion of technology', in Dosi, G., Freeman, C., Nelson, R., Silverberg, G., \& Soete, L. (eds) Technical Change and Economic Theory, Pinter, London, pp. 496-572.

Chiaromonte, F. (2006) Open innovation through alliances and partnership: theory and practice. International Journal of Technology Management, 33(2-3): 111-114.

Christensen, C.M. (1997) The innovator's dilemma: When new technologies cause great firms to fail, Cambridge, Mass., HBS Press.

Christensen, J.F., Olesen, M.H., \& Kjaer, J.S. (2005) The industrial dynamics of Open Innovation Evidence from the transformation of consumer electronics. Research Policy, 34(10): 15331549.

Cohen, W.M. \& Levinthal, D.A. (1990) A new perspective on learning and innovation; Administrative Science Quarterly, 35(1), pp.128-152. 
Cohen, W. \& Levinthal, D., (1989) "Innovation and Learning: the two faces of R\&D," The Economic Journal, 99, 569-596.

Conway, S. \& Stewart, F. (1998) 'Mapping innovation networks', International Journal of Innovation Management, Vol. 2, No. 2, 223-54.

Cooke, P. (2005) Regionally asymmetric knowledge capabilities and open innovation exploring 'Globalisation 2' - A new model of industry organisation. Research Policy, 34(8): 1128-1149.

Cooper, R.G. (1999) The invisible success factors in product innovation," Journal of Product Innovation Management, 16, 2, April 1999, 115-133; R.G. Cooper, "New product leadership: building in the success factors," New Product Development \& Innovation Management, 1,2, 125-140.

Dahlander, L. \& Wallin, M.W. (2006) A man on the inside: Unlocking communities as complementary assets. Research Policy, 35(8): 1243-1259.

Dahlander, L. \& Gann, D.M. (2010) How open is innovation? Research Policy, 39, (6), 699-709.

Dittrich, K. \& Duysters, G. (2007) Networking as a Means to Strategy Change: The Case of Open Innovation in Mobile Telephony, Journal of Product Innovation Management, 24(5): 510-521.

Dodgson, M., Gann D. \& Salter, A. (2006) The role of technology in the shift towards open innovation: the case of Procter \& Gamble, R\&D Management, 36(3), 333-346.

Enkel, E., Gassmann, O. \& Chesbrough, H.(2009) Exploring the phenomenon. R\&D Management Journal, 39(4), 311-316.

Enkel, E. \& Lenz, A. (2009). Open innovation metrics system. Proceedings of the R\&D Management Conference, Vienna, Austria, June 21-24.

Enkel, E., Kausch, C., \& Gassmann, O. (2005) Managing the risk of customer integration. European Management Journal, 23(2): 203-213.

Faulkner, D. (1995) Co-operating to Compete, McGraw-Hill International, Maidenhead.

Fetterhoff, T. J. \& Voelkel, D. (2006) Managing open innovation in biotechnology. ResearchTechnology Management, 49(3): 14-18.

Fleming, L. \& Waguespack, D.M. (2007) Brokerage, Boundary Spanning, and Leadership in Open Innovation Communities, Organization Science, 18(2)165-184.

FredBerg, T., Elmquist, M. \& Ollila. S. (2008) Managing Open Innovation -Present Findings and Future Directions. VINNOVA Report VR, March:02, ISSN: 1650-3104.

Freeman, C. (1982) The Economics of Industrial Innovation, 2nd edn, Frances Pinter, London.

Freeman, C. (1991) Networks of innovators: A synthesis of research issues. Research Policy, 20(5), 499-514.

Gassmann, O. \& Reepmeyer, G. (2005) Organizing Pharmaceutical Innovation: From Sciencebased Knowledge Creators to Drug-oriented Knowledge Brokers. Creativity and Innovation Management, 14(3): 233-245.

Gassmann, O., Sandmeier, P., \& Wecht, C. H. (2006) Extreme customer innovation in the frontend: learning from a new software paradigm. International Journal of Technology Management, 33(1): 46-66.

Gaule, A. (2006) Open Innovation in Action: How to be strategic in the search for new sources of value. London: Blackwell.

Gooroochurn, N. \& Hanley, A., ( 2007) A Tale of Two Literatures: Transaction Cost and Property Rights in Innovation Outsourcing, Research Policy, 36, 1483-1495.

Granstrand, O., Bohlin, E., Oskarsson, C. \& Sjoberg, N. (1992) 'External technology acquisition in large multi-technology corporations', R\&D Management, Vol. 22, No. 2, 111-33.

Gulati, R. (1995) 'Does familiarity breed trust? The implications of repeated ties for contractual choice in alliances', Academy of Management Journal, Vol. 38, No. 1, 85-112.

Hacievliyagil, N.K., Auger, F. \& Hartmann, D. (2008) in preparation.

Hacievliyagil, N.K. (2007) The Impact of Open Innovation on Technology Transfers at Philips and DSM, M.Sc. Thesis Faculty of Technology, Policy \& Management, Delft University of Technology.

Hagedoorn, J. (1990) 'Organisational modes of inter-firm co-operation and technology transfer', Technovation, Vol. 10, No. 1, 17-30. 
Harney, A., 2001, 'Ambitious expansion loses its shine: analysts change their tune about Sony's dreams and begin to count the costs of the new mobile phone alliance with Ericsson', Financial Times, 2 October.

Harryson, S. J. (2008) Entrepreneurship through relationships - navigating from creativity to commercialisation, R\&D Management, vol 38, 3, 291-310.

Henkel, J. (2006) Selective revealing in open innovation processes: The case of embedded Linux. Research Policy, 35(7): 953-969.

Hobday, M., Rush, H., Bessant, J. (2004) Approaching the innovation frontier in Korea: the transition phase to leadership. Research Policy, Dec 2004, vol 33, No 10, 1433-1457.

Hoecht, A. \& Trott, P. (1999), Trust, risk and control in the management of collaborative technology development, International Journal of Innovation Management, vol.3,no1, pp.257270.

Huizingh, E.K.R.E (2011) Open innovation: State of the art and future perspectives. Technovation, $31(1), 1-68$.

Huston, L. \& Sakkab, N. (2007) Implementing open innovation. Research-Technology Management, 50(2): 21-25.

Inkpen, A.C. \& Dinar, A. (1998), "Knowledge management processes and international joint ventures", Organization Science, Vol. 9 No. 4, pp. 454-68.

Jacobides, M.G. \& Billinger, S. (2006) Designing the boundaries of the firm: From "make, buy, or ally" to the dynamic benefits of vertical architecture. Organization Science, 17(2): 249-261.

Kaufman, A., Wood, C.H. \& Theyel, G. (2000) 'Collaboration and technology linkages: a strategic supplier typology', Strategic Management Journal, Vol. 21, 649-63.

Lawson, B. \& Samson, D. (2001) Developing Innovation Capability In Organisations: A DynamicCapabilities Approach, International Journal Of Innovation Management, 5 (3), 377 400

Lefever, D.B. (1992) 'Technology transfer and the role of intermediaries', PhD thesis, INTA, Cranfield Institute of Technology.

Lewis, J.D. (1990) Partnerships for Profit, The Free Press, New York.

Lichtenthaler, U. \& Ernst, H. (2006) Attitudes to externally organizing knowledge management tasks: a review, reconsideration and extension of the NIH syndrome. R \& D Management, 36(4): 367-386.

Lichtenthaler, U. (2007a) The drivers of technology licensing: An industry comparison. California Management Review, 49(4): 67-+.

Lichtenthaler, U. (2007b) Hierarchical strategies and strategic fit in the keepor-sell decision. Management Decision, 45(3): 340-359.

Lichtenthaler, U. \& Ernst, H. (2008) Intermediary services in the markets for technology: Organizational antecedents and performance consequences. Organizational Studies, 29, 100338.

Lincoln, J.R., Ahmadjan, C.L. \& Mason, E. (1998), "Organizational learning and purchase supply relationships in Japan: Hitachoi, Matsushita and Toyota compared", California Management Review, Vol. 40 No. 3, pp. 241-64.

Littler, D.A. (2001) 'Roles and rewards of collaboration', in Tidd J., Bessant J. \& Pault K., Managing Innovation: Integrating Technological, Market and Organisational Charge, 2nd edn, Wiley, Chichester.

Maidique, M. \& Patch, P. (1988) 'Corporate strategy and technology policy', in Tushman, L. \& Moore, W.L. (eds) Readings in the Management of Innovation, HarperCollins, New York.

Mowery, D. (1983) The relationships between intrafirm and contractual forms of industrial research in American manufacturing. Explorations in Economic History, 20.

Nonaka, I. \& Kenney, M. (1991) Towards a new theory of innovation management: A case study comparing Canon, Inc. and Apple Computer, Inc. Jrnl of Engineering and Technology Management, 8, 67-83.

Nonaka, I (1991). The knowledge creating company. Harvard Business Review, 69, Nov-Dec, 96104. 
Norman, P. (2004), "Knowledge acquisition, knowledge loss and satisfaction in high technology alliances", Journal of Business Research, Vol. 57 No. 6, pp. 610-9.

Oxley, J. \& Sampson, R. (2004) The scope and governance of knowledge sharing alliances,

Patel, P. \& Pavitt, K. (2000) 'How technological competencies help define the core (not the boundaries) of the firm', in Dosi, G., Nelson, R. \& Winter, S.G. (eds), The Nature and Dynamics of Organisational Capabilities, Oxford University Press, Oxford, 313-33.

Pearson, A.W. \& Ball, D.F., 1993. A framework for managing communication at the R\&D/Marketing interface. Technovation 13 7, pp. 439-447.

Pearson, A.W., Green, Timothy \& Ball, D.F. (1979), 'A Model for Studying Organizational Effects of an Increase in the Size of R\&D Projects', IEEE Transactions on Engineering Management, Vol. EM- 26, No.1, February 1979, pp.14-21.

Piller, F.T. \& Walcher, D. (2006) Toolkits for idea competitions: a novel method to integrate users in new product development. R \& D Management, 36(3): 307-318.

Rothwell, R. \& Zegweld, W. (1985) Reindustrialisation and Technology, London: Longman.

Rothwell, R. (1992) Successful industrial innovation: critical factors for the 1990's. R \& D Management 22 (3), 64-84.

Rothwell, R., Freeman, C., Horlsey, A., Jervis, V.T.P., Robertson, A.B. \& Townsend, J. (1974) 'SAPPHO updated: Project SAPPHO phase II', Research Policy, 3, 258-91.

Sandulli, F. \& Chesbrough, H. (2009), The two faces of open business models. Working Paper. Available at SSRN:http://ssrn.com/abstract=1325682.

Simard, C. \& West, J. (2006) Knowledge Networks and the Geographic Locus of Innovation, in H. W. Chesbrough \& W. Vanhaverbeke \& J. West (Eds.), Open innovation: Researching a new paradigm: 220-240. Oxford: Oxford University Press.

Tao, J. \& Magnotta, V. (2006) How air products and chemicals "identifies and accelerates". Research Technology Management, 49(5): 12-18.

Teece, D.J. (1986). "Profiting from technological innovation". Research Policy, 15(6), 285-305.

Tidd, J. (1993) Development of Novel Products through intraorganizational and interorganizational networks, Journal of Product Innovation Management, 12, 307-322.

Tilton, J.E. (1971) International Diffusion of Technology: The case of semiconductors. Washington, DC.: The Brookings Institute.

Trott, P. (2008) Managing Innovation \& New product Development, $4^{\text {th }}$ ed., Prentice Hall, London.

Trott, P., Cordey-Hayes, M. \& Seaton, R.A.F. (1995) Inward Technology Transfer as an Interactive process: A case study of ICI, Technovation, 15(1), pp. 25-43.

Trott P., Hartmann, D. (2009) Why 'Open Innovation' Is Old Wine in New Bottles, International Journal of Innovation Management, 13 (4), 715-736

Tushman, M.L. (1978) Task characteristics and technical communication in research and development. Academy of Management Review Jrnl., 20 (2), 75-86.

Tushman, M.L., (1977), 'Technical communication in R\&D laboratories: The impact of project work characteristics', Academy of Management Journal 20, pp.624-645.

Van de Vrande, V., de Jong, J.P.J., Vanhaverbeke, W., \& De Rochemont, M., 2009. Open innovation in SME's: trends, motives andmanagementchallenges. Technovation 29, 423-437.

Van der Meer, H. (2007) Open Innovation - The Dutch Treat: Challenges in Thinking in Business Models. Creativity and Innovation Management, 16(2): 192-202.

Vanhaverbeke, W. (2006) The inter-organizational context of open innovation, in Chesbrough, Vanhaverbeke \& West (Eds.) Open innovation: Researching a new paradigm, Oxford University Press, Oxford, 205-219.

Vyas, N.M., Shelburn, W.L. \& Rogers, D.C. (1995) 'An analysis of strategic alliances: forms, functions and framework', Journal of Business and Industrial Marketing, Summer, Vol. 10, No. 3, 47.

West, J. \& Gallagher, S. (2006) Challenges of open innovation: the paradox of firm investment in open-source software. R \& D Management, 36(3): 319-331. 
West, J., Vanhaverbeke, W., \& Chesbrough, H. W. (2006) Open innovation: A research agenda. In H. W. Chesbrough \& W. Vanhaverbeke \& J. West (Eds.), Open innovation: Researching a new paradigm: 285-307. Oxford: Oxford University Press.

Witzeman, S., Slowinski, G., Dirkx, R., Gollob, L., Tao, J., Ward, S., \& Miraglia, S. (2006)

Harnessing external technology for innovation. Research-Technology Management, 49(3): 19-27. 